\title{
LAW ENFORCEMENT POLICIES IN CRIMINAL ACTS OF CORRUPTION IN INDONESIA
}

\author{
Yopi Gunawan *1四 \\ ${ }^{* 1}$ Faculty of Law, Universitas Singaperbangsa, Indonesia
}

DOI: https://doi.org/10.29121/granthaalayah.v9.i3.2021.3798

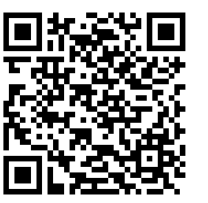

Article Type: Research Article

Article Citation: Yopi Gunawan. (2021). LAW ENFORCEMENT POLICIES IN CRIMINAL ACTS OF CORRUPTION IN INDONESIA. International Journal of Research GRANTHAALAYAH, 9(3), 162-169. https://doi.org/10.29121/granthaa layah.v9.i3.2021.3798

Received Date: 12 March 2021

Accepted Date: 31 March 2021

Keywords:

Law Enforcement

Policy

Corruption

Penal and Non-Penal

\begin{abstract}
The law enforcement of corruption crimes that have been carried out so far only illustrates success in uncovering, arresting, detaining, prosecuting and convicted of the perpetrators who are found guilty. Still, it has not demonstrated success in eradicating corruption crimes widely. So that the success of such efforts creates a perception that Indonesia's corruption crimes are increasing, with this fact, what is illustrated is that Indonesia is a corrupt country. This is undoubtedly a contradiction with the expected goal of eradicating corruption crimes. The purpose of this article is to analyze corrupt law enforcement policies in Indonesia. This article concludes that amid national development efforts in various fields, the public's aspirations in eradicating corruption and any form are increasing because sin has caused enormous losses to the State, which could impact the emergence of crises in various fields. To overcome this, it is necessary to implement penal and non-penal policies to prevent criminal acts of corruption. Thus, the use of correctional and non-penal facilities must go hand in hand in overcoming corruption crimes.
\end{abstract}

\section{INTRODUCTION}

One of the big problems the Indonesian nation faces is corruption, crimes and other issues. The crime of sin has caused devastation for the nation's economy. With the existence of corruption, development in all fields is not going well. The crime of corruption has become an octopus that torments the Indonesian people. Asian tigers that were once carried by Indonesia and respected by Asian countries are now only like toothless tigers with solid teeth and fangs to bite. One of the causes is the corruption crime that thrives in this land. Various efforts have indeed been made to eradicate corruption crimes, but they have not been seen as efforts that can be considered successful until now. The crime of corruption is increasingly fertile, like the growth of rice seeds sowing by farmers. The more it is eradicated, the more people are arrested by the Corruption Eradication Commission (KPK) as suspects of corruption crimes (L. Sarawati, 2017).

Corruption crimes occurred massively and evenly in every state organs line, even as if they were carried out systematically. It is almost indistinguishable between corrupt and non-corrupt acts because immoral actions have become entrenched in life. If not doing them is considered harmful, unethical behaviour is difficult to distinguish between proper, reasonable and correct measures. In law, it is described that the crime of corruption is an act that is detrimental to state finances or the country's economy and hinders national development. Therefore, it must be prevented to create a just and prosperous society. If seen from the perpetrators, most of them are involved in using

(C) 2021 The Author(s). This is an open access article distributed under the terms of the Creative Commons Attribution License, which permits unrestricted use, distribution, and reproduction in any medium, provided the original author and source are credited. 
state money or being paid using state money. If so, the perpetrators of corruption crimes are mostly state officials. Reports on the number of corruption crimes in Indonesia describe many state officials in Indonesia who commit corruption (A. Dahwir, 2017).

The law requires that corruption crimes be prevented because their actions are detrimental to state finances or the country's economy and these actions hinder national development. Since the enactment of the law until today, it has been 18 years old. It is quite a long time since to pass the law to prevent corruption crimes, and corruption crimes should no longer be committed in Indonesia. But the fact is not so; Indonesia Corruption Watch (ICW) 2 noted that in 6 months from 1 January to 30 June 2017, there were 226 cases of corruption in Indonesia. Of these 226 cases, 587 were suspected, with a state loss of Rp. 1.83 trillion (M. K. Gunarto, and L. H. Analisa, 2018).

This fact illustrates that the efforts to eradicate corruption crimes committed for 18 years are meaningless. In the sense that the efforts made for 18 years do not seem to have succeeded in eliminating corruption or reducing sin, it appears that corruption crimes in Indonesia are increasing. Is there something wrong so that it looks as if the crime of corruption cannot be eradicated? This is what we need to ponder. The success of the KPK in exposing, arresting and convicting corrupt criminals on the one hand, maybe some of us will think that this is an extraordinary achievement in the effort to eradicate corruption crimes. Then, do we believe that the real goal of eliminating corruption crimes is to arrest as many people as possible who are suspected of committing corruption crimes? Of course, this is not the case because the more corrupt suspects arrested will only illustrate that corruption crimes are increasing in Indonesia. So, it is not a picture of success or success in eradicating corruption crimes.

An effort to eradicate corruption will be considered prosperous and thriving when the efforts made can prevent someone from committing a corruption crime. Therefore, efforts to eliminate corruption crimes by arresting and convicting the perpetrators are not the ultimate goal. Arrests as many people as possible who are suspected of committing corruption crimes will only create a negative stigma against the state. Therefore, it is necessary to change perspectives and perceptions in efforts to eradicate corruption crimes. Eliminating corruption crimes is a complex undertaking and therefore needs to be carried out integrally. For this reason, this article will discuss how to enforce the law of corruption in Indonesia so that crime is reduced or lost in Indonesia.

\section{DISCUSSIONS}

\subsection{FACTORS CAUSING CORRUPTION CRIME}

Corruption is not an independent event but involves a variety of complex matters. The factors that cause corruption are influenced by the perpetrators' internal characteristics and externals, such as a conducive environment for someone to commit corruption. According to F. Santiago (2017), two things cause corruption to be carried out, namely: 1) Encouragement from within oneself (desire, desire, will and so on); 2) stimulation from outside (encouragement from friends, opportunity, lack of control and so on).

Ferguson (2017) states several causes of corruption, namely: a) The lack of salaries for civil servants is compared to the increasing need; b) Indonesian cultural or cultural background, which is the source or cause of the smooth running of corruption; c) Poor management and less effective and efficient control, which gives people opportunities for corruption; d) Modernization of the development of crime.

The Financial and Development Supervisory Agency (BPKP) (Yusuf, 2013) revealed the factors that cause corruption:

1) Individual Aspects of the Perpetrator, which consists of: a) Human greediness. The possibility of people committing corruption is not because they are poor or have insufficient income. The person may be already rich enough but still has a strong desire to enrich himself. The elements that cause corruption in such perpetrators come from within oneself, namely greed and greed; b) Moral is not strong. A person who is not morally strong tends to be easily tempted to commit corruption. The temptation can come from superiors, subordinates or other parties who provide the opportunity for it; c) Inadequate income, the income of an employee from a job should fulfil a reasonable need of life. If that does not happen, then someone will try to complete it in various ways. But if all efforts are made, it turns out that it is difficult to find, a situation like this will provide an opportunity to commit acts of corruption, be it a corruption of the time, institution, mind, in the sense that all the outpouring of the chance is for purposes outside of the proper work; d) Urgent necessities of life In the life span there is a possibility that a person experiences a critical situation in terms 
of economics. This tightness opens space for someone to take shortcuts, including corruption; e) Consumptive Lifestyle Life in big cities often encourages a consumptive person's lifestyle. If it is not balanced with capital income, this kind of wasteful behaviour will open up opportunities for someone to take various actions to fulfil their needs. One of the possible activities is corruption; f) Lazy or don't want to work. Some people want to get results from a job without breaking a sweat or not being lazy to work. This kind of nature will have the potential to do anything in easy and fast ways, including corruption; and g) Less Practiced Religious Teachings Indonesia is known as a Religious Nation that will certainly prohibit acts of corruption in any form. The reality on the ground determines if sin is still flourishing in the community. This paradoxical situation indicates that religious teachings are less applied in life;

2) Organizational aspects, consisting of a) Lack of exemplary attitude from leadership. The position of a leader in a formal or informal institution has a significant influence on his subordinates. If the administration cannot provide a good role model in front of their associates, such as corruption, the associates will likely take the same opportunities as their superiors; b) Absence of a Correct Organizational Culture usually has a strong influence on its members. If the organizational culture is not managed correctly, it will lead to various situations that are not conducive to colouring the organization's life. In this position, adverse actions, such as corruption, have a chance to occur. The Correct Accountability System in Government Agencies that is inadequate in Government Institutions Generally, it has not formulated the vision and mission it carries, nor has it developed the goals that must be achieved within a specific period mission. As a result, it is difficult for government agencies to assess whether these agencies have succeeded in achieving their targets or not. A further consequence is the lack of attention to the vision of the use of available resources. This situation raises an organizational problem conducive to corrupt practices; c) Weaknesses of Management Control systems Management control is one of the conditions for corruption violations in an organization. The looser / weaker the management control of an organization will be, the more open the corruption acts of members or employees. (d) Management tends to cover up corruption within the organization. In general, management always covers up the crime by a handful of unscrupulous individuals in the organization. As a result of this closed nature, corruption offences continue in various forms;

3) Aspects where individuals and organizations are located, including a) Values in society, are conducive to corruption. The culture of the community can cause corruption. For example, society values a person for the wealth he has. This attitude often makes society uncritical of conditions, such as where the wealth is obtained; b) The public is less aware of corruption's primary victims. The community is still less familiar if the most disadvantaged in this condition is the community. The general public's opinion that the loss due to this condition is the State. Whereas the State loses, the losers are the people also because the development budget process can be reduced due to corruption; c) The public does not realize that they are involved in corruption. Every corruption must include members of the community. The community itself less discovers this. People are often used to being involved in daily corrupt activities in open but unconscious ways; d) The public does not realize that corruption can be prevented and eradicated if the community is active. In general, people think that corruption is the responsibility of the government. The public does not realize that corruption can only be eradicated if the community does so. The public tends to be silent about acts of corruption. In addition to reporting it, also with the consideration that the report will not be responded to honestly. As long as society thinks so, it will be challenging to expect public behaviour to eradicate corruption. Public participation is expected to increase if government regulations provide rewards and incentives to community members credited with exposing corruption; e) Aspects of laws and regulations. Corruption quickly arises because of weaknesses in statutory regulations, which can include monopolistic rules that only benefit cronies in power, inadequate quality of management, principles that are not socialized, sanctions that are too light, application of sanctions that are not sufficient inconsistent and indiscriminate, as well as weak areas of evaluation and revision of laws and regulations.

Corruption always brings negative systemic consequences to democratization and sustainable development. Namely: Corruption delegates the democratic process by reducing public confidence in the political process through money politics. Corruption distorts decision-making in public policy, makes the absence of public accountability, and denies the rule of law (Tarun and Tomczak, 2019). Law and bureaucracy only serve power and capital owners. Corruption eliminates performance-based systems of promotion and punishment because of the patron-client relationship and nepotism. Sin results in development projects and public facilities of low quality and not following the community's needs, thus disrupting sustainable development. Corruption resulted in the collapse of the 
economic system due to uncompetitive products and an accumulation of foreign debt burdens. Systemic corruption causes a) High economic costs by incentive irregularities; b) The political costs of looting or removing a public institution; and c) The social costs of the improper distribution of wealth and power (Xiao, 2013).

\section{HANDLING CORRUPTION CRIME IN INDONESIA}

\subsection{PENAL POLICY}

The current justice system has not been appropriately implemented due to a lack of understanding and ability or even sincerity of those involved in the justice system. Indications of poor service in the judiciary can be felt, seen, and measured by sub-optimal service. Among them are: a) the slow process of investigation; b) failure to prosecute significant cases and attract public attention; c) court decisions that are far from a sense of community justice; d) abuse of power; e) strong KKN, starting from the investigation process to the court's decision and even to its execution (I. Masyitoh, 2017).

The law enforcement process in Indonesia has not run well, so it has not been able to fulfil the sense of justice in society. There are indications that the judicial mafia carries out "buying and selling" of cases, the practice of corruption in almost every judicial process, the existence of executive and legislative intervention against the judiciary so that it is unable to fulfil the sense of justice in society, overlapping laws and regulations, the welfare of the executor judiciary that is still low, and the existing oversight function is ineffective. The weaknesses of the internal supervisory agency are due to a) high solidarity in the form of corps protection (corps geest) in the wrong sense and b) the law of keeping silent when it comes to weaknesses or mistakes of fellow corps or institutions (Januarsyah et al., 2020).

Unwise law enforcement that contradicts people's aspirations is caused by the quality of human resources that are not good enough or the application of an outdated legal spirit. Legal principles that are too rigid, which emphasize too much legal certainty, are detrimental to justice. Other aspirations outside the law are less intensive, for example, jurisprudence, customary law, legal doctrine, and international treaties. Common legal knowledge creates an unprofessional impression and often results in malpractice in the legal field (legal illiteracy aspect). There are still many other practices of taking the law into one's own hands, both between community members and law enforcers against members of the community.

The factors that influence law enforcement are: a) the legal factor itself (law); b) law enforcement factors, namely the parties who form and implement the law; c) factor of means or facilities that support law enforcement; d) community factors, namely the legal environment in effect / applied; e) cultural factors, which are born in the interaction of human life. Of the several factors above, the most important is the factor of law enforcement. The primary law enforcers are the Police as Investigators, Prosecutors as Public Prosecutors, Judges, and Social Institutions Officers. Many law enforcements officers do not understand human rights or deliberately consider power as law. In this regard, it is necessary to increase the professionalism of law enforcement officers and government officials so that they are always concerned with society's development to maintain a balance between legal certainty and justice (Manacorda, 2014).

In improving the criminal justice system's perfection, a method of recruitment and fostering human resources who are: a) knowledgeable is considered as needed; b) well trained; c) have a high skilled. The level of resources described above is expected to: a) professional advancement; b) performance improvement; c) improve behaviour; and d) career development. Demanded from the judge, namely optimal utilization of human potential, effective and efficient ways of working will emerge from them. If the available resources can work effectively and efficiently, the results of the work will be profitable. It is hoped that law enforcers must be professional. This is important to avoid malpractice in the legal field. Less experienced law enforcers often commit malpractice in the legal field (Murphy, 2014).

For a statutory regulation to function correctly, it is necessary to have the harmony of 4 (four) elements, namely: 1) The legal code itself, where there is the possibility of incompatibilities between laws and regulations regarding specific areas of law, other options that what can occur is incompatibilities between statutory rules and unwritten laws or customs that apply in society, and so on; 2) The mentality of officers who use the law. Legal officers (formally), including judges, prosecutors, police, legal advisors/defenders, and so on, must have a good mentality in implementing (applying) a statutory regulation. Otherwise, there will be disturbances or obstacles. In the law 
enforcement system, 3) Facilities are expected to support a legal code's implementation. If a statutory regulation is good, supported by the mentality of the executing officer is also good, but (in specific measures) it is not supported by the availability of inadequate facilities, it will also cause disturbances or obstacles in its implementation; and 4) Citizens as objects, in this case, it is necessary to have legal awareness of the community, legal compliance, and the behaviour of community members as required by legal regulations.

Legal norms will be institutionalized in a particular social system if at least three conditions are met, namely: 1) The most significant proportion of citizens in a social system have accepted these norms; 2) These norms have animated the majority of the members of the social system; 3) The model is sanctioned. Steenhuis provides suggestions or recipes so that criminal law has a high level of efficiency and reflects a good "criminal policy", namely: a) critical review of existing legislation to determine that these provisions are realistic as a criminal law instrument; b) the re-enforcement of all the principles that have been regulated as protection of the public from crime, namely effective prosecution, and the efficiency of criminal law can only be achieved if the direction implemented has the support of the community; c) there are a connection and continuity between the investigative action and the continuation of the prosecution action; d) efficiency is needed by taking into account the ability of the judiciary to use prosecution (formal), and settlement (informal) means; e) develop alternative punishment for crimes that often occur, especially in the process of reprimanding and the rules of evidence; and f) more efficient and effective law enforcement for all types of crimes.

Some of the criticisms aimed at the judiciary include 1) "Slow" dispute resolution, which is the first chronic disease to emerge in the courts worldwide. Settlement of cases through litigation, in general, is "slow" or called "waste on time" (waste of time), this is due to a very formalistic and very technical (technically) examination process; the flow of cases is getting heavier so that the judiciary is overloaded; 2) Case fees are expensive, all parties consider the cost of the chance to be prohibitive, especially if it is related to the length of settlement. The longer the completion, the higher the costs incurred; 3 ) The judiciary is not responsive in the form of behaviour; less responsive in defending and protecting the public interest. In this case, the court's eyes are often closed and generally do not pay attention to the public's interests. Courts are often considered unfair because they only provide services and opportunities, and flexibility to large institutions and the rich. Based on the reality of the judiciary: it is not responsive to serve and defend the interests of "ordinary people" and "ordinary citizens" (ordinary citizens); ordinary people often receive services and treatment that is not fair, even inhuman; 4) The court decision does not solve the problem, the court decision is unable to provide a satisfactory solution to the parties. Court decisions have failed to provide peace and tranquillity to the litigating parties. Court decisions are confusing. Court decisions often do not provide legal certainty (uncertainty) and are unpredictable (unpredictable); 5) The ability of the Judges is a generalist. Judges are considered to have minimal knowledge, only in the field of law. Apart from that, their expertise in general, even layman. Judges with generalist knowledge, it is impossible to resolve disputes that contain the complexity of various fields. Such as construction disputes, directly related to problems in construction technology, accounting, credit and so on (Yusuf, 2013).

In law enforcement related to the image of human rights, there are still many violations, such as a) arrests and detentions that are not immediately accompanied by investigations. Instead, they are often not notified to the family; b) violence, coercion and torture are still occurring during experiments, so that some die or experience lifelong disabilities; c) persecution still frequently happens in detention centres or child prisons, so that some people experience disabilities or die; d) discriminatory treatment based on power or wealth, so that it still reflects differences in treatment (unequal treatment) either functionally or institutionally; e) fraud often occurs in criminalizing Civil disputes or levelling off criminal acts; f) the process of solving cases that are contrary to the principles of justice is simple, fast and low cost; g) the right to be accompanied by a legal advisor at the investigation stage, still lacks proper service (A. Prakarsa and R. Yulia, 2017).

Philosophically, idealism, the formulation of legislation (law) is for the sake of upholding justice. Rules are made solely to fulfil and respond to society's interests, which must be established wisely and fairly. The reality or form if justice is successfully upheld and presented to the community has at least several indications, among others, that the community feels protected and guaranteed its security from various modes of confiscation of their property and is compensated for the losses it has suffered, the graph of a qualified crime shows a decrease and the realization of role recognition and the position of social inequality before the law. Law enforcers are expected to be able to bridge the idealism of equality before the law is manifested in reality, meaning that normative rules are the content of legislation that is relied on to become an engineering force in the community demanding the competence of law enforcers to carry it out honestly and openly (fair trial and transparency). 
Correct and just law enforcement must start from the postulate of civilization, society, and etiquette. Only law enforcement that contains values of culture and humanity, and propriety can achieve truth and justice. Every law enforcement starts from the importance of civilization and society and etiquette, approaching truth and justice. Law enforcement is not merely upholding statutory regulations and laws, but must be aimed at enforcing the truth and justice, and the reasons are: a) wetmatig (legal) is not necessarily rechtvaardig (just); b) something that is rechmatig (lawful) is not necessarily rechtvaardig (just).

However, following the values of civilization and humanity and decency, they must contain truth and justice values. Following developments, "justice" has put forward a postulate, namely an argument that states philosophically, essential justice is the values that are following humanity, civilization and decency. Every human, society and propriety value that is following the circumstances of the place, environment and time in which members of the community feel the community concerned lives as genuinely appropriate and just.

\subsection{NON-PENAL POLICY}

A. N. Marbun (2017) said that crimes could be viewed: a) from a juridical perspective, namely acts that are prohibited by law and offenders are threatened with sanctions; b) in terms of criminology, namely works that violate the norms prevailing in society and get an adverse reaction from the community; c) in terms of psychology, namely abnormal human actions that violate legal standards, which are caused by psychological factors from the perpetrator of the act.

A rational policy for tackling crime is called criminal politics. Criminal procedure, when viewed in scope, is extensive and high in complexity. In essence, crime is a humanitarian problem and a social problem that requires a different understanding. Crime as a social problem is a dynamic symptom, constantly growing and associated with other complex social symptoms and structures, constituting a socio-political problem. Concerning the use of penal and non-penal means, the use of non-penal means is given a more significant portion than the use of corrective means, meaning that there is a need in the context of overcoming corruption. This understanding is oriented to achieve conducive factors that cause corruption to arise (factor criminogen). Criminology occupies an important position and the role of criminology, which through research understands the nature and background of crime, explores and finds non-penal means, a criminological approach is needed in the use of penal means.

According to AN Marbun (2017), to combat crime in a general, conceptual way, it is carried out by combining various elements related to the criminal justice mechanism and community participation, which can be explained as follows: a) Increasing and strengthening law enforcement officials, including organizational strengthening, personnel and infrastructure for settlement of criminal cases; b) Legislation that can function to analyze and stem crime and have a reach into the future; c) An effective criminal justice mechanism with fast, precise, cheap and straightforward requirements; d) Coordination among law enforcement officials and other related government officials, to increase the effectiveness in overcoming crime; e) Community participation in helping smooth the implementation of crime prevention.

About "crime prevention" includes the following steps: a) Development and Improvement of Law Enforcement Officials which includes organizational structure, personnel, and equipment, which is aligned with the development of criminal patterns, which is influenced by developments in society and technology; b) make use of criminal justice procedures and mechanisms, which are aligned with the image of tackling crime, such as trials that are fast, cheap, precise and indiscriminate; c) reforming legislation, in line with the demands of social and technological developments; d) Coordination between law enforcers, among government officials whose duties are related to the prevention of crime and law enforcement officials. Coordination is integral/integrated for law enforcement; e) community participation in crime prevention, by fostering a sense of security and purpose of responsibility for regional security and order (A. Dahwir, 2017).

The definition of criminal policy can be divided into 3 (three) meanings, namely: 1) In a narrow sense, it is the whole principles and methods that are the basis of reactions to legal violations in the form of crimes; 2) In a broad sense, is the overall function of the law enforcement apparatus, including the workings of the courts and the police; 3 ) In the general sense, it is the whole policy, carried out through legislation and official bodies, which aims to uphold the central norms of society. A rational policy to tackle crime is called criminal politics, which is very broad in scope and high in complexity. Crime is both a humanitarian problem as well as a social problem. Crime as a social problem 
is a dynamic symptom, growing and associated with other signs and complex social structures, constituting a sociopolitical problem.

The correlation between the development of crime and society's structure in all its aspects (social, economic, political and cultural) is an essential requirement for crime prevention. Crime prevention policies are linked to social politics. The goal of criminal procedure is the welfare of society. Criminal politics is an integral part of approaches to achieve social welfare. The crime prevention policy takes steps, namely the modification of penal and non-penal measures. Criminal politics is that of the need to integrate crime prevention policies with social politics and law enforcement politics. The crime prevention policy is modified by the politics of public welfare and the politics of protecting society in general. Efforts to control crime need to be pursued with a policy approach, in the sense that a) there is integration between criminal politics and social politics; and b) there is an integration between the prevention of crime with penal and non-penal.

It appears that there is a demand for a crime prevention strategy in the form of reducing and eliminating the conditions that cause crimes to occur. Through penal means, policy measures cannot prevent crime because following "prevention without punishment" measures to combat corruption utilizing punitive means must be accompanied by efforts to combat crime through non-penal means. Concerning the use of penal and non-penal means, especially for crime prevention policies, the conditions are no different. The use of non-penal means is given a more significant portion than the use of penal means, meaning that there is a need to overcome crime. This understanding is oriented to achieving the conducive factors that cause crime (criminogen factors).

Criminology occupies an essential position in addition to criminology, which through research understands the nature and background of crime and explores and finds non-penal means, a criminological approach is needed in the context of the use of penal means. The use of punitive and non-penal means requires an understanding oriented to looking for conducive factors that cause crime (criminogen factors). This is where criminology's role appears, by carrying out research activities, both classical, positivist and interactionist in nature, which can contribute to gain understandings about the nature and background of the occurrence of crime. A criminological approach is also needed in the context of the use of penal means. In the corrective means, there are problems with criminal law in the sense of ius constitutum and ius constituendum.

According to Soedjono Dirdjosisworo, in the effort to combat crime in a general, conceptual way, it is carried out by combining various elements related to the criminal justice mechanism and public participation: a) Increasing and strengthening law enforcement officials, including supporting organizations, personnel and infrastructure for solving criminal cases; b) Legislation that can function to analyze and stem crime and have a reach into the future; c) An effective criminal justice mechanism with fast, precise, cheap and straightforward requirements; d) Coordination among law enforcement officials and other related government officials, to increase the effectiveness in overcoming crime; e) Community participation in helping smooth the implementation of crime prevention.

Concerning "crime prevention", it includes the following steps: a) Development and Improvement of Law Enforcement Officials which includes organizational structure, personnel, and equipment, which are aligned with the development of criminal patterns, which are influenced by developments in society and technology; b) Make use of criminal justice procedures and mechanisms, which are aligned with the image of tackling crime, such as trials that are fast, cheap, precise and indiscriminate; c) Renewal of legislation, in line with the demands of social and technological developments; d) Coordination between law enforcers, among government officials whose duties are related to the prevention of crime and law enforcement officials. Coordination is integral/integrated for law enforcement; e) community participation in crime prevention, through fostering security and a sense of responsibility for regional security and order (Xiao, 2013).

\section{CONCLUSION}

The weak eradication of corruption in Indonesia, especially in the regions, is that apart from the lack of law enforcers with broad legal insight, law enforcers who dare to clash with power are also lacking. Law enforcers only dare perpetrators who are weak in control, former officials, or business people who do not have reliable back-up power. It seems like selective cutting of the perpetrators of corruption who are brought to justice. Public aspirations to eradicate corruption and other forms of irregularities are increasing because, in reality, acts of corruption have caused enormous losses to the State, which can impact the emergence of crises in various fields. To overcome this, penal and non-penal policies need to be carried out by taking actions to prevent criminal acts of corruption. The 
decentralization policy has fostered corruption at the local level. The rise of allegations of corruption cases occurred not long after the implementation of the regional autonomy policy or government decentralization, with the issuance of Law Number 22 of 1999 concerning Regional Government which replaced Law Number 5 of 1974 concerning Regional Government, regional government institutions had more power especially in budget management arrangements, which have implications for the opening of opportunities for corruption, in this regard, it is necessary to conduct a review of the authority of local governments, especially in the use of finance.

\section{SOURCES OF FUNDING}

This research received no specific grant from any funding agency in the public, commercial, or not-for-profit sectors.

\section{CONFLICT OF INTEREST}

The author have declared that no competing interests exist.

\section{ACKNOWLEDGMENT}

None.

\section{REFERENCES}

[1] A. Dahwir, "Rekonstruksi Sanksi Pidana Dalam Undang-Undang Pemberantasan Tindak Pidana Korupsi di Indonesia (Punishment Oriented)," Lex Publica, Jurnal Ilmu Hukum Asosiasi Pimpian Perguruan Tinggi Hukum Indonesia, vo. 6, pp. 655-667, November, 2017.

[2] A. N. Marbun, "Suap di Sektor Privat: dapatkah Dijerat?," Integritas, Jurnal Anti Korupsi KPK, vol. 3, pp. 72-85, Maret, 2017.

[3] A. Prakarsa and R. Yulia, "Model Pengembalian Aset (Asset Recovery) Sebagai Alternatif Memulihkan Kerugian Negara Dalam Perkara Tindak Pidana Korupsi," Jurnal Hukum PRIORIS, vol. 6, pp.31-44, Maret, 2017.

[4] F. Santiago, "Penegakan Hukum Tindak Pidana Korupsi oleh Penegak hukum untuk Terciptanya Ketertiban Hukum,” Pagaruyuang Law Journal, vol. 1, pp. 33-46, July, 2017.

[5] Ferguson, G. (2017). Global Corruption: Law, Theory, and Practice. International Centre for Criminal Law Reform and Criminal Justice Policy. Vancouver, BC, CA.

[6] I. Masyitoh, "Dinamika Pelaksanaan Fungsi Legislasi Dewan Perwakilan Rakyat Daerah Provinsi Dalam Penyelenggaran Pemerintahan Daerah," Jurnal Ilmu Hukum Litigasi, vol. 10, pp. 102-117, Februari, 2009.

[7] Januarsyah, Mas Putra Zenno et al. Corrective Justice: An Economic Approach for Law. Journal of Advanced Research in Law and Economics, [S.l.], v. 10, n. 1, p. 208-215, feb. 2020.

[8] L. Sarawati, "The Function of Ideal Law in Preparation Regulation Legislation in order to Creating Eqitable Regional Development.” Diponegoro Law Review, vol. 02, pp. 117-129, July, 2017.

[9] M. K. Gunarto, and L. H. Analisa, "Kebijakan Formulasi Hukum Pidana Dalam Penanggulangan Tindak Pidana Korupsi," Jurnal Hukum Khaira Ummah, vol. 13, pp. 37-49, Maret, 2018.

[10] Manacorda. (2014). Preventing Corporate Corruption: The Anti-Bribery Compliance Model, Switzerland: Springer International Publishing.

[11] Murphy, A.G. (2011). Foreign Corrupt Practices Act: A Practical Resource for Manager and Executives. Wiley. Hoboken, N.J.

[12] Tarun, R.W. and P.P. Tomczak. (2019). The Foreign Corrupt Practices Act Handbook: A Practical Guide for Multinational Counsel, Transactional Lawyers, and White-Collar Criminal Practitioners. American Bar Association. Lanham.

[13] Xiao, Michael Yangming. "Deferred/Non-Prosecution Agreements: Effective Tools to Combat Corporate Crime", Cornell Journal of Law and Public Policy, Vol.23, No.233 (2013).

[14] Yusuf, M. (2013). Merampas Aset Koruptor: Solusi Pemberantasan Korupsi di Indonesia, Jakarta: Kompas. 